\title{
Long-term performance of different aluminum alloy designs as sacrificial anodes for rebars
}

\author{
O. de Rincón*, M. Sánchez*, M. de Romero*, G. Paz* and W. Campos*
}

Abstract This paper presents the performance of various cathodic-protection designs using Aluminum alloys to protect prestressed piles. The results obtained with different system designs (bracelete type-Al/Zn/In alloy, thermosprayed aluminum (3-year evaluation) and conventional $\mathrm{Al} / \mathrm{Zn} / \mathrm{In}$ anodes in an epoxy-painted steel bracelet (12-year evaluation)), indicated that all of these systems may be used as sacrificial anodes for pile protection. However, the thermosprayed aluminum type can not be used in prestressed concrete piles because the very negative potentials $\left(<-1100 \mathrm{mV}\right.$ vs. $\left.\mathrm{Cu} / \mathrm{CuSO}_{4}\right)$ they supply to the reinforcement could lead to hydrogen embrittlement.

Keywords Cathodic protection. Prestressed piles. Corrosion. Aluminum alloys anodes.

\section{Comportamiento a largo plazo de diferentes diseños de aleaciones de aluminio como ánodos de sacrificio para armadura}

\begin{abstract}
Resumen Este trabajo presenta la realización de varios diseños de protección catódica utilizando aleaciones de aluminio para la protección de pilotes pretensados. Los resultados obtenidos con diferentes diseños (aleación de $\mathrm{Al} / \mathrm{Zn} / \mathrm{In}$, tipo brazalete y aluminio termorociado ( 3 años de evaluación) y ánodos convencionales de $\mathrm{Al} / \mathrm{Zn} / \mathrm{In}$ colocados en un brazalete de acero pintado con epoxy (12 años de evaluación)), indicaron que todos estos sistemas pueden ser utilizados como ánodos de sacrificio para la protección de los pilotes. Sin embargo, el sistema con aluminio termorociado no puede ser utilizado en pilotes de acero pretensado debido al potencial muy negativo alcanzado por la armadura $(<-1100 \mathrm{mV}$ vs $\left.\mathrm{Cu} / \mathrm{CuSO}_{4}\right)$, lo cual podría inducir a daños por hidrógeno.
\end{abstract}

Palabras clave Protección catódica. Pilotes pretensados. Corrosión. Ánodos de aleaciones de aluminio.

\section{INTRODUCTION}

The past few years have seen an increase in research on the use of sacrificial anodes for the cathodic protection of the reinforcement in reinforced concrete structures. This increase is due not only to simplicity of application and low system-maintenance requirements, but also to its application in prestressed concrete structures, in which the risk of hydrogen embrittlement would be eliminated, given the low and controlled protection potential.

Zinc is one of the materials that have undergone major evaluation, especially in the US ${ }^{[1-9]}$. However, because of its low protective capacity in time, the location of the system is under constant modification. A new system, known as "ZincHydrogel", was recently designed in an effort to control this situation. This system, which consists of a sheet of zinc foil backed by an ion-conducting adhesive, appears to be producing better results ${ }^{[2 \text { and } 5]}$.

This system has been under study at Centro de Estudios de Corrosión (CEC), Universidad del Zulia, since $1984^{[10-13]}$, following a promising line for the use of an $\mathrm{Al} / \mathrm{Zn} / \mathrm{In}$ alloy in specific situations, especially for prestressed piles in tide and splash areas ${ }^{[12]}$. Studies have therefore lately been centered on the search for a safe and easy way to install these anodes embedded in highstrength porous mortar ${ }^{[13]}$ designed to allow corrosion-product diffusion from this aluminum

(*) Centro de Estudios de Corrosión, Facultad de Ingeniería - Universidad del Zulia Maracaibo - Venezuela. Tel/Fax:58-61598784/525732. 
alloy. Other investigators, Funahashi ${ }^{[14]}$ among them, have been evaluating an Al-12/Zn-0.2/In alloy, with very good results.

This work presents the latest results obtained with three different anode locations: Bracelet-type $\mathrm{Al} / \mathrm{Zn} / \mathrm{In}$, thermosprayed Al. (3-year evaluation) and conventional $\mathrm{Al} / \mathrm{Zn} / \mathrm{In}$ anodes in an epoxycoated steel bracelet (12-year evaluation).

\section{EXPERIMENTAL PART}

\subsection{Experimental reinforced concrete piles with cathodic protection system}

Four cylindrical reinforced concrete piles were built (Table I): $(\varnothing=15.24 \mathrm{~cm}$; height: $160 \mathrm{~cm})$. Chloride at $0.1 \% \mathrm{w} / \mathrm{w}$ (concrete-based), was added to the mixture.

The reinforcements in these piles are a steel structure, which is the metallic element to be protected by applying cathodic protection. The steel structure comprises three rebars with $\varnothing=1.27 \mathrm{~cm}(1 / 2$ in $) \times 150 \mathrm{~cm}$ long, joined together with a helicoidal rebar $0.653 \mathrm{~cm}(1 / 4$ in $) \times 414 \mathrm{~cm}$ (total area: $0.261 \mathrm{~m}^{2}$ ). The rebars were welded at several points to ensure greater electrical continuity. Graphite was used for the reference electrodes (embedded in the concrete), which were prepared according to the CEC procedure ${ }^{[15]}$. The electrodes were located $3 \mathrm{~mm}$ from the reinforcement, at two (2) different heights: at $50 \mathrm{~cm}$ and $1 \mathrm{~m}$ from the top of the reinforcement. $\mathrm{A} \mathrm{Cu} / \mathrm{CuSO}_{4}$ external electrode was also used for measuring potentials.

\subsubsection{Al/Zn/In anodes}

The $\mathrm{Al} / \mathrm{Zn} / \mathrm{In}$ alloy was fused in accordance with the green and dry-sand molding method ${ }^{[15]}$. The anodes consist of two $1.8 \mathrm{~cm}$ thick $\times 120 \mathrm{~cm}$ long bracelet shells (Fig. 1).

A hole was drilled into the upper part of the bracelets, into which a screw was later inserted, with a No. 12 TW plaited cable soldered to it. The cable was later covered with an epoxy resin that

Table I. Mixture used for experimental concrete piles

Tabla I. Mezcla utilizada para los Pilotes de Concreto Experimentales

\begin{tabular}{cccc}
\hline $\begin{array}{c}\text { Cement } \\
(\%)\end{array}$ & $\begin{array}{c}\text { Coarse aggregate } \\
(\%)\end{array}$ & $\begin{array}{c}\text { Fine aggregate } \\
(\%)\end{array}$ & $\begin{array}{c}\text { Water } \\
(\%)\end{array}$ \\
\hline 14.60 & 45.60 & 30.40 & 9.40 \\
\hline
\end{tabular}

serves as an insulator and prevents the formation of a galvanic couple at that point. This connection would later be used for applying the cathodic protection system (anode-metal structure). A hole was also made in each bracelet in order to measure the reinforcement potentials vs. $\mathrm{Cu} / \mathrm{CuSO}_{4}$ once they had been placed on the piles. The two shells were screwed together with galvanized bolts. At each contact point, epoxy resin was spread on the outside of the bolt nuts to avoid the formation of a galvanic couple.

\subsubsection{Aluminum anode}

Located on one of the piles by thermospraying, using COR Resist 29220 powder supplied by Eutetic + Castolin. When the anode was in place, two rawlplugs (to be used for installing the cables for the cathodic protection system) were inserted into the pile.

In both cases, a mortar, specially evaluated in $\mathrm{CEC}^{[13]}$ for this specific situation, was cast after the anodes were in place. Chloride $(0.1 \% \mathrm{w} / \mathrm{w})$ was added to the mixture. Of the four piles, two were fitted with aluminum bracelet-type anodes; one with a thermosprayed aluminum anode and the fourth was left unprotected as reference control (for comparison). Once installed, mortar was cast to embed the anodes and create the electrolyte that would allow the cathodic protection system to act (Fig. 1). Reinforcement potentials were measured before connecting the cathodic protection system, using a multimeter and the graphite electrode embedded in the concrete, as well as the purpose-built $\mathrm{Cu} / \mathrm{CuSO}_{4}$ electrode inserted in the orifices. All of these piles, including one with conventional anodes in an epoxy-coated steel bracelet ${ }^{[13]}$ (previously exposed for 12 years) and embedded in the same mortar, were placed on a purpose-built bench (Fig. 2a), which was then submerged in Lake Maracaibo (Fig. 2b).

\subsection{Electrochemical measurements}

The cathodic protection potential was measured periodically on all piles, using the graphite electrode embedded in the concrete and an external $\mathrm{Cu} / \mathrm{CuSO}_{4}$ electrode. The current drained by the anode was determined one year after the system was installed. A cathodic depolarization test using both electrodes was then run. The corrosion rate of the $\mathrm{Al}$ and $\mathrm{Al} / \mathrm{Zn} / \mathrm{In}$ anodes and the resistivity 

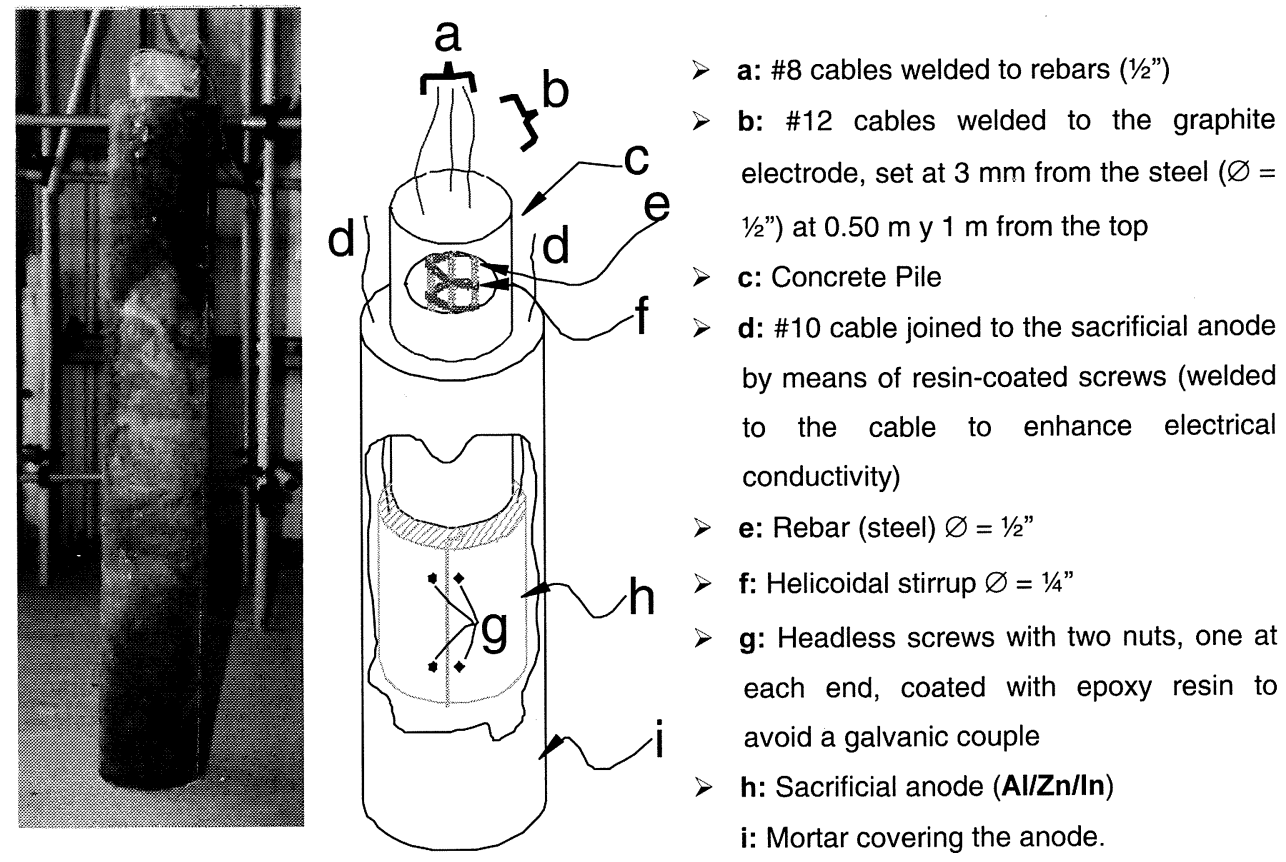

Figure 1. Cathodic protection system on pile with $\mathrm{Al} / \mathrm{Zn} / \mathrm{ln}$ bracelet.

Figura 1. Sistema de protección catódica de un pilote con ánodos de $\mathrm{Al} / \mathrm{Zn} / \mathrm{ln}$.

of the concrete in which the anode was embedded were measured using GECORR6 ${ }^{[16]}$.

\subsection{Anode/concrete interface analysis}

Scanning Electron Microscopy (SEM) was used to evaluate the Anode/Mortar and Anode/Concrete interface to determine anode oxidation-product diffusion through the mortar/concrete. To that effect, $2.5 \mathrm{~cm}$ diameter cores were extracted from each cylinder at the level of one of the reinforcement steel bars. Core length depended on the rebar location.

\section{RESULTS AND DISCUSSION}

\subsection{Electrochemical Evaluation}

Figures 3 and 4 show the average reinforcement potential variation after the sacrificial anodes were connected and the test piles located in Lake Maracaibo. Protection potentials are obtained in all cases, with more negative potentials obtained from the one thermosprayed with Al. However, the potentials reached with the $\mathrm{Al} / \mathrm{Zn} / \mathrm{In}$ anodes, after approximately 3 years exposure, are in the order of $-900 \mathrm{mV}$ vs. $\mathrm{Cu} / \mathrm{CuSO}_{4}$.

Figures 5 and 6 show the depolarization tests results. The test piles protected with the bracelettype anodes reached depolarization values $>100 \mathrm{mV}$ after $4 \mathrm{~h}$. However, this was not observed with the piles thermosprayed with Al. Apparently, one of the rawlplugs used for the electrical connection to the anode through the cable made contact with the reinforcement; so when the cables were disconnected externally, the reinforcement potential remains very low.

Average currents, measured at the end of the exposure period, were $5.7 \mathrm{~mA} / \mathrm{m}^{2}$ and $4.9 \mathrm{~mA} / \mathrm{m}^{2}$ for the system with $\mathrm{Al} / \mathrm{Zn} / \mathrm{In}$ anodes (bracelet type) and Al (thermosprayed), respectively. These currents coincide with the ones used to protect reinforced concrete in several countries ${ }^{[1,5,7,8,13}$ and 15$]$.

Figure 7 shows the results of the test piles exposed approximately 12 years ago ${ }^{[12]}$, with $\mathrm{Al} / \mathrm{Zn} / \mathrm{In}$ anodes distributed on an epoxy-coated steel bracelet. Note that potentials are still at protection levels $\left(<-850 \mathrm{mV}\right.$ vs. $\left.\mathrm{Cu} / \mathrm{CuSO}_{4}\right)$ after all this time. In this case, the current drained is $4.3 \mathrm{~mA} / \mathrm{m}^{2}$.

Additionally, after depolarization, the test piles were allowed to become completely depolarized and the corrosion rate of Aluminum and the 


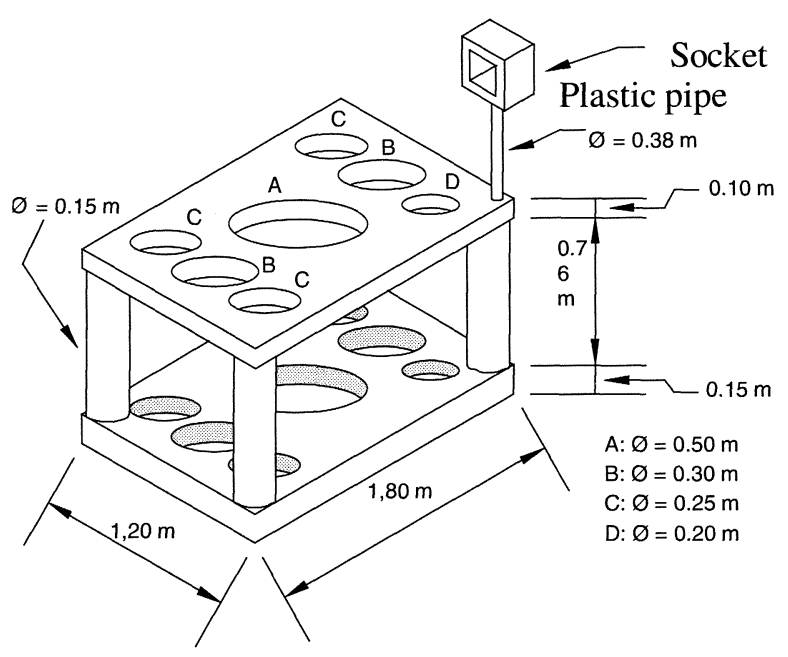

(a)

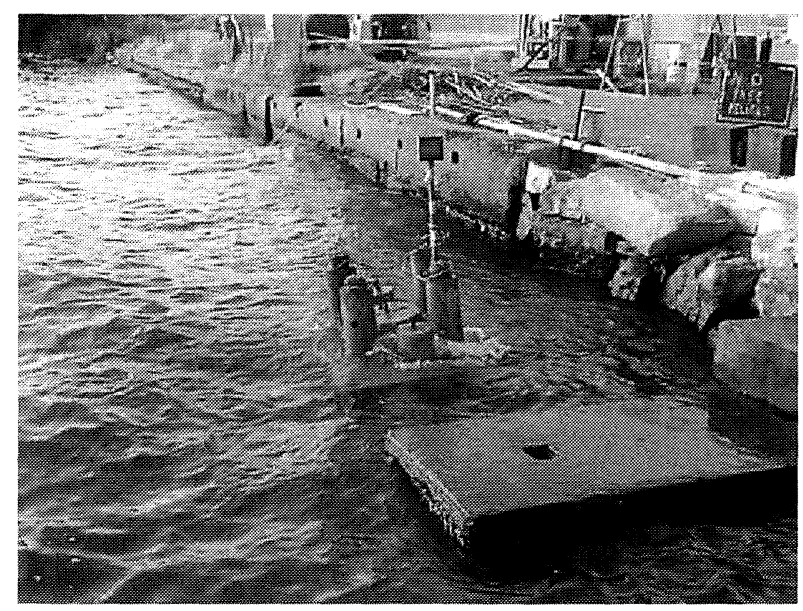

(b)

Figure 2. a) Workbench. b) Workbench with the different piles submerged in Lake Maracaibo.

Figura 2. a) Mesa de trabajo. b) Mesa de trabajo con los diferentes pilotes sumergidos en el Lago de Maracaibo.

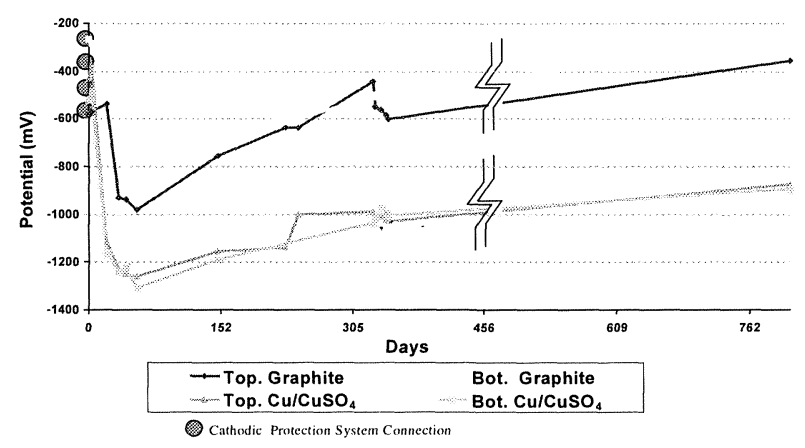

Figure 3. Pile with bracelet-type anodes: Reinforcement potencial variation with time, before and after inmmersion.

Figura 3. Pilote con los ánodos tipo brazalete: Variación con el tiempo del potencial del refuerzo, antes y después de la inmersión.

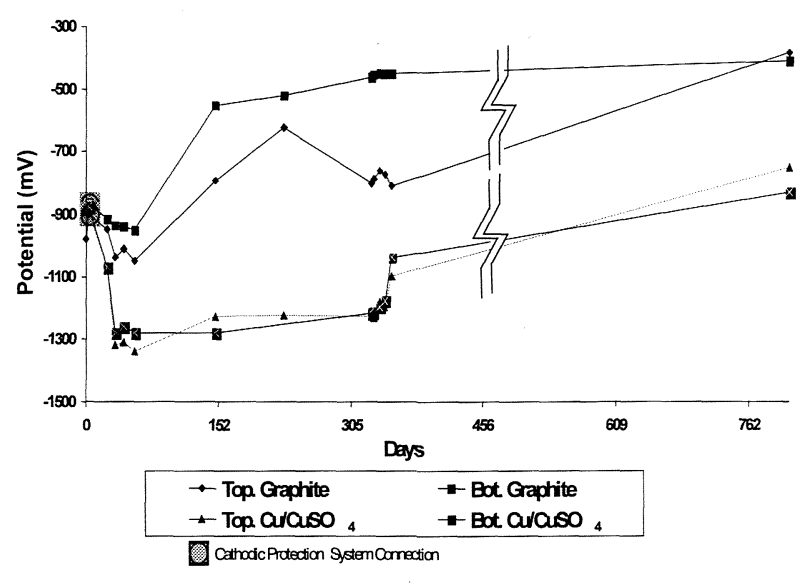

Figure 4. Pile with thermosprayed anodes: Reinforcement potencial variation with time, before and after inmersion.

Figura 4. Pilote con los ánodos termorrociados: Variación con el tiempo del potencial del refuerzo, antes y después de la inmersión.

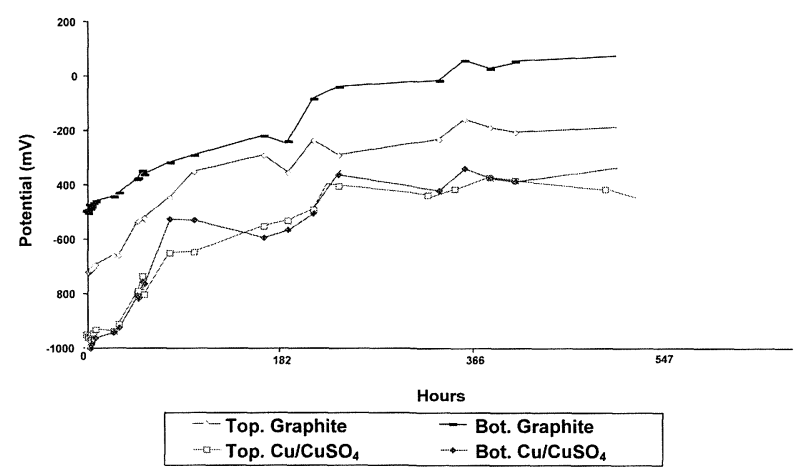

Figure 5. Pile with bracelet-type anodes: Depolarization curves.

Figura 5. Pilote con los ánodos tipo brazalete: Curvas de despolarización.

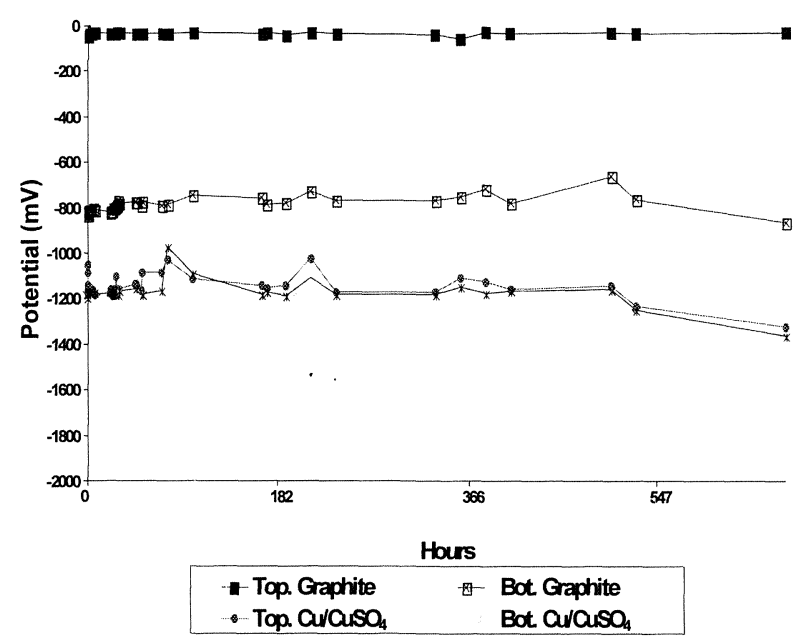

Figure 6. Pile with thermosprayed anodes: Depolarization curves.

Figura 6. Pilote con los ánodos termorrociados: Curvas de despolarización. 
$\mathrm{Al} / \mathrm{Zn} / \mathrm{In}$ alloy was assessed, as well as the electrical resistance and resistivity of the mortar embedding the anodes. Table II shows the results.

It can be seen that the corrosion rate is not very high $(0.012-0.031 \mathrm{~mm} /$ year for the $\mathrm{Al} / \mathrm{Zn} / \mathrm{In}$ and $\mathrm{Al}$ anode, respectively), which would give a prolonged useful life to these anodes. However, the Al-thermosprayed anode has the least corrosion potential $\left(<-1000 \mathrm{mV}\right.$ vs. $\left.\mathrm{Cu} / \mathrm{CuSO}_{4}\right)$ and greater corrosion rates $\left(3.543 \mu \mathrm{A} / \mathrm{cm}^{2}(0.031 \mathrm{~mm} /\right.$ year $)$, approximately), which is not needed for guaranteeing reinforcement protection. On the contrary, this would mean a shorter useful life for the anodes and a more negative potential for the reinforcement something that could be harmful for prestressed steel. It was also observed that the resistivity of the mortar covering the anodes remains low and almost constant, regardless of anode type $(5 \mathrm{k} \Omega \cdot \mathrm{cm})$, which is good for conducting the galvanic current in the electrolyte.

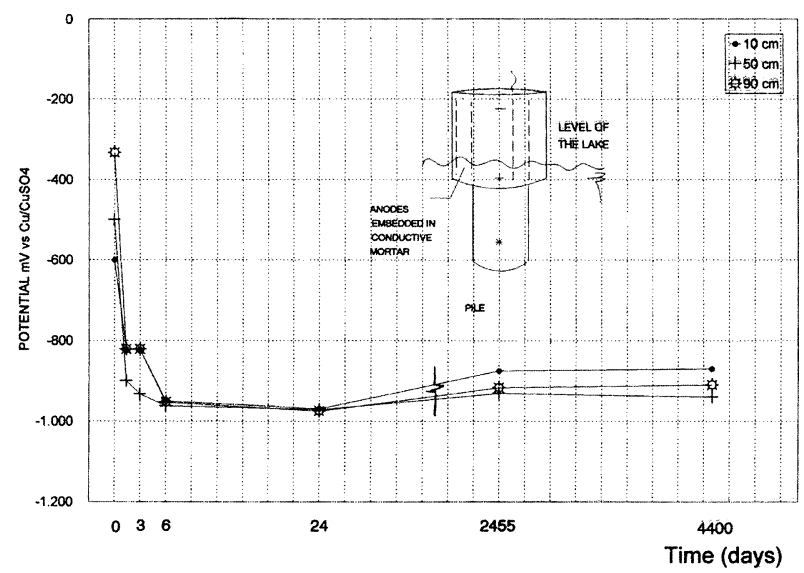

Figure 7. Piles with $\mathrm{Al} / \mathrm{Zn} / \mathrm{In}$ anodes distributed on an epoxy-coated steel bracelet.

Figura 7. Pilotes con ánodos de $\mathrm{Al} / \mathrm{Zn} / \mathrm{In}$ distribuidos sobre un brazalete de acero revestido con epoxi.
The unprotected cylinder was also evaluated (Fig. 8). Note the low potentials, indicative of reinforcement corrosion. The corrosion rate measured was also very high $\left(>0.5 \mu \mathrm{A} / \mathrm{cm}^{2}\right)$, as expected.

\subsection{Anode/Concrete, Anode/ Mortar Interface SEM analysis}

Al diffusion through the mortar/concrete was observed in all cases. Figure 9 shows a typical case, the morphology of the area evaluated for the Althermosprayed anode/embedding mortar interface and mapping per element $(\mathrm{Al}, \mathrm{Ca}, \mathrm{Cl})$. Note the $\mathrm{Al}$ corrosion-product diffusion toward the outside as it goes further away from the anode/mortar interface, as well as $\mathrm{Cl}$ enrichment at the interface.

It is important to point out that no cracks were observed in the mortar embedding the anodes when the cores were extracted. However, an inside crack was seen at the anode/concrete interface in some parts of the cylinders in which the bracelettype anode was inserted. This might have occurred

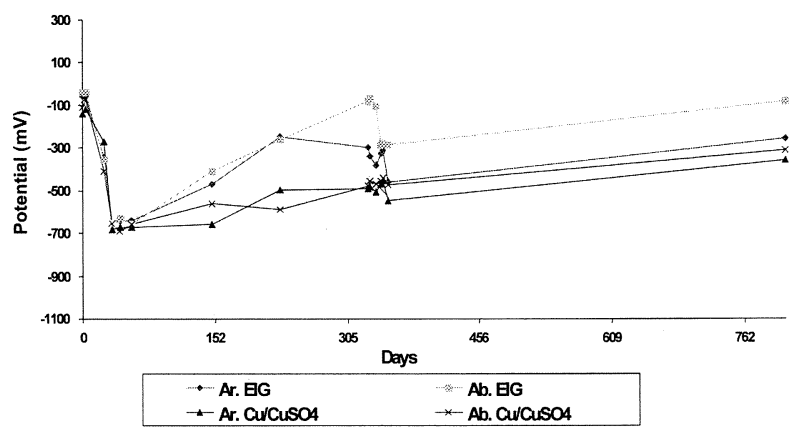

Figure 8. Test-Pile reinforcement potential variation with time, before and after immersion.

Figura 8. Pilote de prueba: Variación con el tiempo del potencial del refuerzo, antes y después de la inmersión.

Table II. Electrochemical parameters of the different sacrificial anodes evaluated

Tabla II. Parámetros electroquímicos de los eiferentes ánodos de sacrificio evaluados

\begin{tabular}{|c|c|c|c|c|c|}
\hline \multirow[b]{2}{*}{ ANODE TYPE } & \multirow{2}{*}{$\left(\mathrm{mV}\right.$ vs. $\left.\mathrm{Cu} / \mathrm{CuSO}_{4}\right)$} & \multirow[b]{2}{*}{$\begin{array}{c}\mathbf{i}_{\text {corr }} \\
\mu \mathrm{A} / \mathrm{cm}^{2} \\
\text { (mm/year) }\end{array}$} & \multicolumn{3}{|c|}{ PARAMETERS EVALUATED } \\
\hline & & & $\begin{array}{l}\mathbf{R} \\
\Omega\end{array}$ & $\begin{array}{c}\rho \\
\mathrm{K} \Omega \cdot \mathrm{cm}\end{array}$ & $\begin{array}{c}\mathbf{E}, \mathbf{i}, \rho \\
\text { Averages }\end{array}$ \\
\hline \multirow{3}{*}{ Bracelet $(\mathrm{Al} / \mathrm{Zn} / \mathrm{In})$} & -964.6 & $1.73(0.015)$ & 0.21 & 7.39 & -962.9 \\
\hline & -963.4 & $1.588(0.14)$ & 0.29 & 3.12 & 1.22 \\
\hline & -960.8 & $0.910(0.008)$ & 0.20 & 5.06 & 5.19 \\
\hline \multirow{3}{*}{ Thermosprayed (Al) } & -1150.5 & $4.144(0.036)$ & 0.29 & 4.59 & -1149.5 \\
\hline & -1149.3 & $3.887(0.034)$ & 0.30 & 7.03 & 3.543 \\
\hline & -1149.2 & $2.598(0.023)$ & 0.30 & 4.53 & 5.38 \\
\hline
\end{tabular}



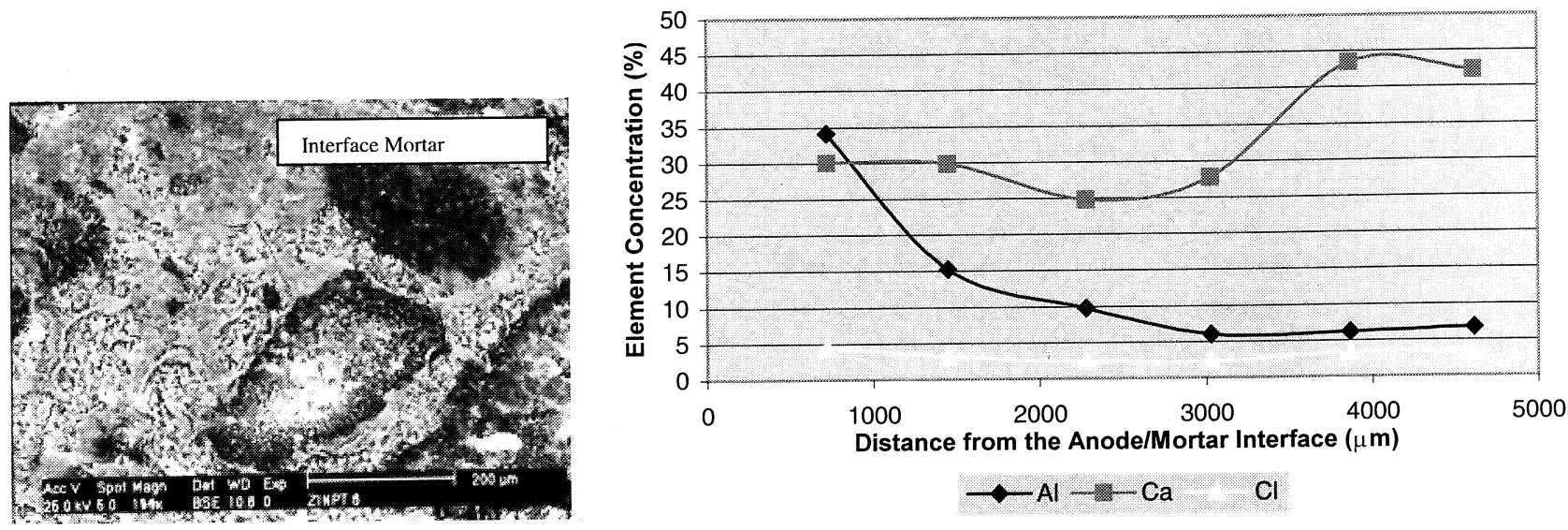

Figure 9. a) Morphology of the area evaluated for the interface of the Al-thermosprayed anode/embedding mortar and b) mapping per element ( $\mathrm{Al}, \mathrm{Ca}, \mathrm{Cl}$ ).

Figura 9. a) Morfología del área evaluada en la interface ánodo de Al Termorrociado/Mortero y b) Mapeo por Elemento (Al, (a, Cl).

at the time this anode was installed in the concrete cylinder. However, this did not affect reinforcement polarization, as can be seen in figures 3, 4 and 8. Some localized fissures were also seen in the spots where the anode was connected to the reinforcement.

\section{CONCLUSIONS}

The following conclusions may be drawn from the electrochemical evaluations:

- $\mathrm{Al} / \mathrm{Zn} / \mathrm{In}$ anodes (bracelet type) may be used as sacrificial anodes for protecting prestressed piles.

- The Al anode (thermosprayed type), may also be used as a sacrificial anode, but no in prestressed steel piles because they supply very negative potentials to the reinforcement -which could lead to hydrogen brittleness.

- The resistivity of the mortar covering the anodes remains low and constant, regardless of anode type $(5 \mathrm{~K} \Omega \cdot \mathrm{cm})$, which is good for conducting the galvanic current in the electrolyte.

\section{Acknowledgements}

The authors would like to thank the CYTED (DURACON Project), for promoting and financing the interchange of ideas and knowledge with the Iberoamerican researchers.

\section{REFERENCES}

[1] A.A. SAGÜÉs and R.G POWers, Corrosion 52 (1996) 508 522.

[2] J.E. Bennett and C. Firlotte, Mat. Performance, 36-3 (1997) 14-20.

[3] R.B. Hartman and W.H. Hillier, Corrosion/97, paper No. 250. New Orleans, 1997, NACE International (Eds.), Houston, TX , 1997.

[4] R.J. Kessler, R.O. Powers and I.R. Lasa, Mat. Performance, 37-1 (1998) 12-16.

[5] R.B. Hartman and J.B. Wehling, Proc. International Conference on Corrosion and Rehabilitation of Reinforced Concrete Structures, Orlando, FL, December, 1998, CD Publication No. FHWA-SA-99-014, Federal Highway Administration, USA, 1998.

[6] G.G. Clemeña, D. Jackson, W. Young and M. FunAHASHI, Proc. International Conference on Corrosion and Rehabilitation of Reinforced Concrete Structures, Orlando, FL, December, 1998, CD Publication No. FHWA-SA-99-014, Federal Highway Administration, USA, 1998.

[7] J.B. BenNeTt, Proc. International Conference on Corrosion and Rehabilitation of Reinforced Concrete Structures, Orlando, FL, December, 1998, CD Publication No. FHWA-SA-99-014, Federal Highway Administration, USA, 1998.

[8] S.K. LEE, Y.M. SIGONNEY, W.H. HARTT and R.U. LEE, Proc. International Conference on Corrosion and Rehabilitation of Reinforced Concrete Structures, Orlando, FL, December, 1998, CD Publication No. FHWA-SA-99-014, Federal Highway Administration, USA, 1998.

[9] B.S. Covino JR, S.J. Bullard, G.R. Holcomb, J.H. Russell, S.D. Cramer, J.E. BennetT and H.H. Laylor, Proc. International Conference on Corrosion and Rehabilitation of Reinforced Concrete Structures, Orlando, FL, December, 1998, CD Publication No. FHWA-SA-99-014, Federal Highway Administration, USA, 1998. 
Long-term performance of different aluminum alloy designs as sacrificial anodes for rebars

O. DE RinCón, M. SÁNCHEZ, M. DE ROMERO, G. PAZ AND W. CAMPOS

[10] O. Troconis de Rincón, A. Romero de Carruyo and O. García, Rev. Téc. Fac. Ing. Edición Especial 10-1 (1987).

[11] O. Troconis de Rincón, D. Contreras, M. FernándeZ de Romero, O. Morón and J. Bravo, Mat. Performance 35-8 (1996) 14-21.

[12] O. Troconis de Rincón, M. Fernández de Romero, A. romero de Carruyo, M. Sánchez and O. García, Mat. Const. 30 (1997) 556-560.

[13] O. Troconis de Rincón, A. Romero de Carruyo, D. ROMERO and E. CUICAS, Corrosion 48 (1992) 960-966.
[14] M. Funahashi, and W.T. Young, CORROSION/99, paper No. 550, NACE International (Eds.), Houston TX, 1999.

[15] G. PAZ, Eng. Degree Theses, Escuela de Ingeniería Civil, Facultad de Ingeniería, Universidad del Zulia Maracaibo, Venezuela. 2000.

[16] S. feliú, J.A. González, S. Feliú Jr., M. Escudero, I. Maribona, V. Austin, C. Andrade, J. Bolaño and F. JiMENEZ, U.S. Patent, No. 5.259.944, 1993. 